\title{
Arginine Vasopressin and Atrial Natriuretic Peptide Do Not Alter Ion Transport by Cultured Fetal Distal Lung Epithelium
}

\author{
HUGH O'BRODOVICH, BIJAN RAFII, AND PAUL PERLON \\ Department of Pediatrics and Hospital for Sick Children Research Institute, University of Toronto, \\ Ontario, Canada M5G 1 X8
}

\begin{abstract}
Previous studies have shown that i.v. arginine vasopressin (AVP) decreases but does not stop lung fluid secretion in term fetuses not in labor. Although it has been presumed that the response to AVP results from augmented sodium transport, there is controversy whether AVP actually does affect sodium transport in mammalian lung epithelium. To determine if AVP or aldosterone could alone or together augment sodium transport in the perinatal lung, we studied primary cultures of fetal rat distal lung epithelium in Ussing chambers. The short circuit current of these sodium-transporting cells was not affected by the application of either 30 or $300 \mathrm{mU} / \mathrm{mL}$ AVP whether or not they were previously exposed to aldosterone $\left(10^{-6} \mathrm{M}\right)$. Aldosterone also did not affect the baseline bioelectric properties. Short circuit current increased in response to 8-bromo cAMP $\left(10^{-4} \mathrm{M}\right)$ and 3-isobutyl-1-methylxanthine $\left(10^{-3} \mathrm{M}\right)$ to levels $169 \pm 16(\mathrm{SEM})$ and $172 \pm 7 \%$ of respective baseline values. AVP had no effect in cells pretreated with 3-isobutyl-1-methylxanthine. Monolayers also did not respond to atrial natriuretic peptide $\left(10^{-11}\right.$ to $10^{-8} \mathrm{M}$ ). Monolayers of Na-absorbing A6 renal epithelium did increase short circuit current with either aldosterone or AVP. AVP increased endogenous cAMP levels in A6 but not fetal rat distal lung epithelium cells, suggesting that fetal rat distal lung epithelium lacks $V_{2}$ receptors. These studies demonstrate that AVP does not increase ion transport in cultured fetal distal lung epithelium although these cells possess the necessary second messenger system. (Pediatr Res 31: 318-322, 1992)
\end{abstract}

\section{Abbreviations}

AVP, arginine vasopressin

FLE, fetal rat distal lung epithelium

Isc, short circuit current

IBMX, isobutyl-1-methylxanthine

$8 \mathrm{Br}$, bromoadenosine

HBSS, Hanks' balanced salt solution

$\mathrm{PD}$, potential difference

$R$, resistance

ANP, atrial natriuretic peptide

MEM, minimum essential medium

At birth, the newborn lung is filled with fluid, which must be cleared before efficient gas exchange can take place. Epithelial

Received February 27, 1991; accepted December 16, 1991.

Correspondence and reprint requests: Dr. Hugh O'Brodovich, Respiratory Research Division, Hospital for Sick Children Research Institute, 555 University Ave., Toronto, Ontario, Canada M5G 1 X8.

Supported by the Medical Research Council of Canada grant PG-42. H.O'B. is a Career Investigator of the Heart and Stroke Foundation of Ontario. active sodium transport likely plays an important role in this perinatal lung water clearance, inasmuch as in vivo experiments have demonstrated that the sodium transport blocker amiloride can block $\beta$-agonist-induced fluid absorption in the fetal lamb lung (1) and delay fluid clearance in newborn guinea piglets (2). Studies using amiloride analogs have also suggested that the ability of amiloride to delay postnatal lung water clearance results from its blockade of epithelial sodium channels (3). To investigate mechanisms that could increase this perinatal lung epithelial sodium transport, we chose to study AVP because it reduces fluid secretion in fetal goats (4) and lambs (5) and circulates in the fetus in increased concentrations during normal delivery (6).

Numerous studies (e.g. Refs. 7-11) have demonstrated that AVP can increase sodium transport in some non-lung tissues by increasing the number of active membrane-associated sodium channels (10). It is unknown whether these observations can be extrapolated to different species or to different epithelial membranes. For example, it has been reported that the AVP increases sodium transport in the rat's (8) but not the rabbit's (9) cortical collecting duct. The effect of AVP on lung epithelial Na transport is similarly uncertain. Although AVP reduces fluid secretion in term intrauterine fetal lambs and goats $(4,5)$, it has no effect on $\mathrm{Na}$ transport by the rabbit tracheal epithelium (12). The effect of AVP on $\mathrm{Na}$ transport by adult alveolar epithelial cells is also unclear; it has been reported to increase dome formation (13), yet Cott et al. (14) reported that AVP had no effect on the bioelectric properties of adult type II alveolar epithelial cells. Studies of adult type II alveolar cells (15) also suggest that adult type II alveolar epithelium possesses $A V P V_{1}$ but not $V_{2}$ receptors, the latter being associated with the cAMP signal transduction pathway.

We performed in vitro experiments to determine whether AVP affected ion transport by perinatal distal lung epithelium. We studied primary cultures of FLE because these cells possess the bioelectric characteristics of sodium transporting epithelia and, similar to in vivo studies, transport sodium via sodium channels $(3,16,17)$. Cells were studied in the presence or absence of aldosterone because this hormone might affect the response of the epithelium to $\operatorname{AVP}(7,9,11,18,19)$.

\section{MATERIALS AND METHODS}

Cell culture. FLE cells were harvested according to methods previously described by ourselves (16) and others (20) and were grown in primary cultures. In brief, timed gestation $20 \mathrm{~d}$ (term $=22 \mathrm{~d}$ ) fetal Wistar rats had their lungs removed and minced into $1-\mathrm{mm}^{3}$ pieces. The lung fragments were incubated at $37^{\circ} \mathrm{C}$ with $0.125 \%$ trypsin and $0.002 \%$ DNAse, and the liberated cells were subsequently passed through a Nitex (B \& S.H. Thompson, Scarborough, Ontario, Canada) 100 mesh filter. The cells were then incubated with $0.1 \%$ collagenase and purified using a dif- 
ferential adhesion and centrifugation technique $(16,20)$. After each incubation step, protease activity was stopped using $5 \%$ FCS. More than $95 \%$ of the cells were cytokeratin-positive as assessed by the PPK-1 antibody. Most cells have the morphologic, biochemical, intracellular filament, and lectin-binding characteristics of type II alveolar epithelial cells (21), but because either precursor type II epithelial cells or airway cells may also be present we refer to these cells as fetal rat distal lung epithelial cells (FLE cells).

The $\mathrm{Na}$ absorbing amphibian (Xenopus laevis) A6 renal epithelial cell line was obtained from the American Type Culture Collection (Rockville, MD). Cells were cultured in a $5 \% \mathrm{CO}_{2} /$ balance air environment at $26^{\circ} \mathrm{C}$ using NCTC 109 media plus $10 \% \mathrm{FCS}$ and $15 \%$ water (to dilute to appropriate osmolality for amphibian tissues). Cells were maintained in plastic tissue flasks and used between passages 74 and 77 .

Bioelectric measurements. The harvested and purified FLE cells were immediately seeded $\left(\sim 1.0 \times 10^{6}\right.$ cells $\left.\cdot \mathrm{cm}^{-2}\right)$ onto Transwell tissue culture treated polycarbonate filters (Co-Star, Cambridge, MA). All cells were initially grown in MEM $+10 \%$ FCS at $37^{\circ} \mathrm{C}$ under a $95 \%$ air: $5 \% \mathrm{CO}_{2}$ environment. Unattached cells were removed $24 \mathrm{~h}$ after seeding. The bioelectric properties of the monolayers of type II cells were studied 2 to $4 \mathrm{~d}$ after initial harvest by placing the filters in Ussing chambers (MRA, Clearwater, FL) that contained $37^{\circ} \mathrm{C}$ HBSS and $21.4 \mathrm{mM} \mathrm{Na}-$ $\mathrm{HCO}_{3}$.

A6 cells underwent brief trypsinization $(0.25 \%)$ and then were seeded at $1 \times 10^{6}$ cells $\cdot \mathrm{cm}^{-2}$ on similar filters and cultured as described above. Seven $\mathrm{d}$ after seeding the A6 cells, the monolayers were studied in the same Ussing chambers using the $26^{\circ} \mathrm{C}$ HBSS with $21.4 \mathrm{mM} \mathrm{NaHCO}$ diluted by $15 \%$ to maintain appropriate electrolyte concentrations for these amphibian cells.

In approximately one half of the experiments, a $1 \%$ bovine albumin in normal saline solution had been used to condition the fluid reservoirs and prevent potential loss of added peptide through adsorption to the glass. The solution was then removed, chambers rinsed, and fresh protein-free HBSS was then circulated by an airlift equilibrated with $95 \%$ room air: $5 \% \mathrm{CO}_{2}$. Subsequent studies without such albumin pretreatment showed similar results for FLE, and all experiments were combined. Bioelectric properties of the cell monolayers were monitored with $\mathrm{KCl}$ agarcalomel half-cells and silver-silver chloride electrode-saline agar bridges that were connected to a high-impedance millivoltmeter that could function as a voltage current clamp with automatic fluid resistance compensation (VCC 600 Physiologic Instruments, San Diego, CA). The transepithelial monolayer PD was clamped to $0 \mathrm{mV}$ so that an Isc could be continuously recorded. Every $10 \mathrm{~s}$ the monolayer was clamped to $1 \mathrm{mV}$ for $0.5 \mathrm{~s}$ so that measured change in Isc enabled calculation of $\mathrm{R}$ using Ohm's law. Every $10 \mathrm{~min}$, the epithelium was briefly placed under open circuit conditions so that spontaneous PD could be determined. Reported Isc values refer to the movement of positive charge from the apical to basolateral side of the membrane, and the PD is referenced to the apical side (basolateral side was positive relative to apical side). We only studied monolayers of FLE cells whose $\mathrm{R}>100 \Omega \cdot \mathrm{cm}^{2}$ and PD $>0.7 \mathrm{mV}$ (more than $90 \%$ of monolayers met these bioelectric criteria). We used the same criteria for A6 cells except for those that were not pretreated with aldosterone, and then only the $\mathrm{R}$ criterion was used (it is known that without aldosterone pretreatment the Isc and PD are reduced).

Experimental protocols for FLE. A variety of experimental protocols were used because hormonal treatment, such as aldosterone (7), is known to alter the response of some sodiumtransporting tissues to AVP. For all protocols, the monolayers were cultured in MEM $+10 \%$ FCS for $24 \mathrm{~h}$ after seeding cells onto filters.

Preliminary experiments $(n=3)$ were performed on monolayers that remained in MEM $+10 \%$ dialyzed FCS until they were placed in the Ussing chamber. Isc did not change when either 30 or $300 \mathrm{mU} / \mathrm{mL}$ of AVP were applied to both sides of the monolayer (data not shown). A possible explanation for the lack of response to AVP was inadequate dialysis of the serum with residual hormones masking an effect. Therefore, subsequent experiments determined the effect of AVP on FLE monolayers that were placed in serum-free MEM ( \pm added $10^{-6}$ aldosterone) for $24 \mathrm{~h}$ before experimentation. Experiments were also performed to investigate whether $24 \mathrm{~h}$ of serum deprivation by itself would affect the bioelectric properties of FLE, i.e. $24 \mathrm{~h}$ before placing the filter in the Ussing chamber, some monolayers were placed in MEM without FCS $(n=19)$. During the study, baseline bioelectric parameters were recorded and then $10^{-4} \mathrm{M}$ amiloride was added to the apical side of the membrane to document the presence of sodium transport. Although Isc was continuously recorded, the reported bioelectric parameters are values obtained 10 min after addition of the amiloride to the apical side of the monolayer.

Four groups of FLE monolayers were studied to determine if AVP would affect the bioelectric properties of FLE monolayers growing on polycarbonate filters. Twenty-four $\mathrm{h}$ before study, the control $(n=6)$ and AVP alone $(n=4)$ groups were placed in serum-free media, whereas the aldosterone + AVP $(n=6)$ group had $10^{-6} \mathrm{M}$ aldosterone in the serum-free media.

In all groups, baseline bioelectric variables were measured and sufficient AVP was added to achieve final concentrations of 30 and then $300 \mathrm{mU} / \mathrm{mL}$ of AVP in both basolateral and apical sides of the cells. After each dose of AVP, Isc was continuously monitored for up to $30 \mathrm{~min}$, and then cells were exposed to $10^{-4}$ $M$ amiloride.

The above experiments showed that AVP did not increase Isc (see Results). Because the effect of AVP in other Na-transporting tissues is likely mediated via cAMP (22), we wished to determine that FLE could respond to a cAMP stimulus. A similar protocol was used in cells that were serum-deprived for $24 \mathrm{~h}$. After determining baseline values and exposing the cells to 30 and 300 $\mathrm{mU} / \mathrm{mL}$ AVP, we added a membrane-permeant cAMP analog, $8 \mathrm{Br}$ cAMP (final concentration $10^{-4} \mathrm{M}$ ), to the apical and basolateral side of the cells $(n=4)$. Additional studies $(n=7)$ were also performed in which we added IBMX (final concentration $10^{-3} \mathrm{M}$ ) to both sides of the monolayer to inhibit degradation of endogenously produced cAMP, and in four of these monolayers we exposed the cells $1 / 2 \mathrm{~h}$ later to either the saline vehicle or 30 then $300 \mathrm{mU} / \mathrm{mL}$ of AVP. The IBMX was dissolved in DMSO, with the final concentration of DMSO/Ussing chamber fluid being 1:1000. This amount of DMSO has been previously shown by us to not affect the bioelectric properties of FLE (16).

Because our results showed that AVP did not increase Isc, we also evaluated whether ANP [a peptide that affects renal sodium transport (23)] or its putative second messenger, cGMP, affected the bioelectric properties of FLE. After establishing baseline bioelectric values, we added sufficient ANP to both sides of the monolayer to achieve log incremental concentrations ranging from $10^{-11}$ through $10^{-8} \mathrm{M}$. Additional experiments determined the effect of $8 \mathrm{Br}$ cGMP (membrane permeant cGMP analogue, $1 \mathrm{mM}$ apical and basal) on FLE bioelectric parameters.

Experimental protocols for A6 renal epithelium. Because our experiments had shown that neither AVP nor aldosterone affected the bioelectric properties of FLE, we studied these compounds on A6 cells to prove their biologic activity. Some of the monolayers were treated with aldosterone $\left(10^{-6} \mathrm{M}\right)$ in serumfree media for $24 \mathrm{~h}$ before placement in the Ussing chambers. When in the Ussing chambers, the monolayers were either exposed to concentrations of 30 and then $300 \mathrm{mU} / \mathrm{mL}$ of AVP (apical and basolateral) or a $1 \mathrm{mM}$ concentration of $8 \mathrm{Br}$ cGMP (apical and basolateral).

cAMP measurements. Because our studies demonstrated that membrane-permeant cAMP analogs or IBMX could, whereas AVP could not, alter the bioelectric properties of FLE, we measured the endogenous cAMP levels in FLE and A6 cells (cAMP assay kit; Amersham, Oakville, Canada). FLE or A6 cells 
were cultured on Transwell permeant polycarbonate filters (similar to those used in Ussing chamber experiments) at a seeding density of 250000 cells $\cdot \mathrm{cm}^{-2}$. The cells were placed in serumfree media containing $10^{-6} \mathrm{M}$ aldosterone $24 \mathrm{~h}$ before assay. Cells were treated with $1 \mathrm{mM}$ IBMX (initially dissolved in DMSO with final DMSO:water = 1:1000) for 20 min after exposure to the agent of interest. Monolayers of either A6 or FLE cells were then extracted for subsequent assay at time $=0 \mathrm{~min}$ (baseline) or $10 \mathrm{~min}$ after addition of vehicle (control), terbutaline $\left(10^{-5}\right.$ M), or AVP (300 mU/mL). Six monolayers of each cell type were studied at each of the above time points. cAMP levels were normalized for $\mathrm{mg}$ protein by assaying the protein content of monolayers of A6 or FLE cells grown on similar filters (average of two filters of each cell type).

Reagents. IBMX, AVP (four separate shipments), ANP, $8 \mathrm{Br}$ cAMP, $8 \mathrm{Br}$ cGMP, aldosterone, and amiloride were obtained from Sigma Chemical Co. (St. Louis, MO) and stored according to manufacturer's instructions. HBSS, MEM, FCS, and trypsin were obtained from Gibco (Grand Island, NY), and collagenase and DNAse were obtained from Worthington Biochemicals (Freehold, NJ).

Statistics. All results are reported as means \pm SEM. Differences between two groups or between baseline and a single experimental intervention were assessed with an unpaired and paired $t$ test, respectively. Differences between multiple groups or multiple experimental interventions was assessed by a one-way analysis of variance followed by least significant difference or Tukey's $t$ tests. Probability $<0.05$ was considered significant.

\section{RESULTS}

Fetal lung epithelium bioelectric properties. Twenty-four h of serum deprivation had small but significant effects on the FLE monolayers (Table 1). Although both groups were studied in Ussing chambers containing HBSS, the monolayers exposed to serum-free MEM for $24 \mathrm{~h}$ had a significantly lower PD and nonsignificant trends toward a lower Isc and R. As previously reported $(3,16)$, the sodium transport inhibitor amiloride $\left(10^{-4}\right.$ $\mathrm{M})$ inhibited the majority of Isc in both groups. The amount of amiloride-sensitive Isc was similar in the MEM + FCS $(3.8 \mu \mathrm{A}$. $\left.\mathrm{cm}^{-2}\right)$ and serum-free MEM $\left(3.8 \mu \mathrm{A} \cdot \mathrm{cm}^{-2}\right)$; however, the residual Isc postamiloride was less in serum-free monolayers $(p<0.05)$.

The groups that were to receive the saline vehicle (control), AVP only (AVP), or AVP in monolayers exposed to $10^{-6} \mathrm{M}$ aldosterone (AVP + ALDO) during the preceding $24 \mathrm{~h}$ had no significant differences (one-way analysis of variance) in their baseline bioelectric properties (Table 2). Similarly, none of these groups responded to either 30 or $300 \mathrm{mU} / \mathrm{mL}$ final concentration of AVP (Table 3). Isc was continuously recorded, and no transient effects were seen. This dose was not toxic to the cells as illustrated by stable $R$ (data not shown) and Isc values being similar to control filters (Table 3 ). The monolayers were observed for $1 \mathrm{~h}$ after addition of the initial AVP dose; thus, there was sufficient time to see a response if the cells possessed appropriate receptors and signal transduction pathways (e.g. Ref. 8). At the end of the protocol, amiloride $\left(10^{-4} \mathrm{M}\right)$ decreased the Isc to 11 $\pm 2,7 \pm 1$, and $9 \pm 11 \%$ of baseline values in the control, AVP,

Table 1. Effect of $24 \mathrm{~h}$ of serum-free MEM on bioelectric properties of fetal alveolar epithelium*

\begin{tabular}{lccccc}
\multicolumn{3}{c}{ MEM $+10 \%$ FCS } & & Serum-free MEM \\
\cline { 2 - 3 } \cline { 5 - 6 } & Baseline & $\begin{array}{c}\text { Amiloride } \\
\left(10^{-4} \mathrm{M}\right)\end{array}$ & Baseline & $\begin{array}{c}\text { Amiloride } \\
\left(10^{-4} \mathrm{M}\right)\end{array}$ \\
\hline Isc $\left(\mu \mathrm{A} \cdot \mathrm{cm}^{-2}\right)$ & $5.6 \pm 0.4$ & $1.8 \pm 0.2 \dagger$ & & $4.8 \pm 0.3$ & $1.0 \pm 0.1 \dagger \ddagger$ \\
$\mathrm{PD}(\mathrm{mV})$ & $2.6 \pm 0.3$ & $1.0 \pm 0.1 \dagger$ & $1.6 \pm 0.3 \ddagger$ & $0.3 \pm 0.06 \dagger \ddagger$ \\
$\mathrm{R}\left(\Omega \cdot \mathrm{cm}^{2}\right)$ & $482 \pm 41$ & $515 \pm 40$ & $343 \pm 59$ & $361 \pm 60$ \\
\hline
\end{tabular}

${ }^{*}$ Results are mean \pm SEM; $n=19$ each group.

$\dagger p<0.01$ relative to respective baseline value.

$\ddagger p<0.05$ relative to $\mathrm{MEM}+10 \% \mathrm{FCS}$ group.
Table 2. Baseline bioelectric values for FLE and renal A6 cells*

\begin{tabular}{lccc} 
& $\mathrm{PD}(\mathrm{mV})$ & $\mathrm{Isc}\left(\mu \mathrm{A} \cdot \mathrm{cm}^{-2}\right)$ & $\mathrm{R}\left(\Omega \cdot \mathrm{cm}^{2}\right)$ \\
\hline FLE groups & & & \\
$\quad$ Control $(n=6)$ & $2.5 \pm 0.6$ & $4.3 \pm 0.4$ & $518 \pm 96$ \\
AVP, no ALDO $(n=$ & $2.3 \pm 0.6$ & $3.9 \pm 0.3$ & $562 \pm 133$ \\
$\quad$ 4) & & & \\
ALDO + AVP $(n=$ & $1.7 \pm 0.3$ & $5.6 \pm 0.5$ & $395 \pm 79$ \\
$\quad$ 6) & & & \\
A6 groups & & \\
$\quad$ No ALDO $(n=4)$ & $0.5 \pm 0.6$ & $0.8 \pm 0.1$ & $1514 \pm 255$ \\
ALDO treated $(n=$ & $2.3 \pm 0.67 \dagger$ & $2.4 \pm 0.35 \dagger$ & $855 \pm 171$ \\
$\quad$ 12)
\end{tabular}

* Results are data before addition of AVP. All monolayers were cultured in serum-free MEM \pm aldosterone $(A L D O)$.

$\dagger p<0.05$ relative to monolayers not treated with aldosterone.

Table 3. Isc $\left(\mu \mathrm{A} \cdot \mathrm{cm}^{-2}\right)$ after sequential addition of AVP to FLE and renal $A 6$ cells

\begin{tabular}{llcc}
\hline & \multicolumn{1}{c}{ AVP } & AVP \\
& Baseline & $(30 \mathrm{mU} / \mathrm{mL})$ & $(300 \mathrm{mU} / \mathrm{mL})$ \\
\hline FLE groups & & & \\
$\quad$ Control $(n=6)$ & $4.3 \pm 0.51$ & $3.9 \pm 0.47$ & $3.8 \pm 0.46$ \\
AVP $(n=4)$ & $3.9 \pm 0.31$ & $3.5 \pm 0.35$ & $3.4 \pm 0.41$ \\
$\quad$ ALDO + AVP $(n=6)$ & $5.6 \pm 0.49$ & $5.0 \pm 0.43$ & $4.6 \pm 0.38$ \\
A6 groups & & & \\
AVP $(n=4)$ & $0.8 \pm 0.10^{*}$ & $0.6 \pm 0.05^{*}$ & $0.7 \pm 0.12^{*}$ \\
ALDO + AVP $(n=5)$ & $3.4 \pm 0.58$ & $6.1 \pm 0.38 \dagger$ & $6.3 \pm 0.22 \dagger$ \\
\hline
\end{tabular}

$* p<0.05$ relative AVP values.

$\dagger p<0.05$ relative to baseline values.

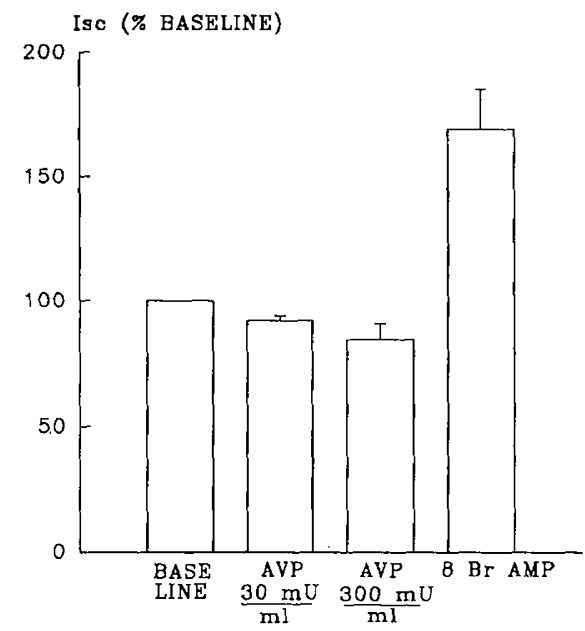

Fig. 1. The Isc of FLE monolayers $(n=4)$ were not affected by exposure of both sides of the cells to 30 or $300 \mathrm{mU} / \mathrm{mL}$ of AVP, yet subsequently showed a marked increase in response to $8 \mathrm{Br}$ cAMP $\left(10^{-4}\right.$ $M)$. The monolayers were sequentially exposed to the above drugs at 30 min intervals; thus, the epithelium had a total of $60 \mathrm{~min}$ to respond to $30 \mathrm{mU} / \mathrm{mL}$ and $30 \mathrm{~min}$ to respond to the $300 \mathrm{mU} / \mathrm{mL}$ of AVP dose.

and AVP + ALDO groups, respectively. These results confirm our preliminary results, from which we were unable to show an effect of AVP on monolayers of FLE that were cultured in serumcontaining MEM until they were studied in Ussing chambers (data not shown). Additional studies $(n=3)$ determined if lower doses of AVP $(0.03,0.3$, and $3 \mathrm{mU} / \mathrm{mL})$ would affect Isc. Similar to the higher dose studies, no effect was seen. The Isc after these lower doses were, respectively, $90 \pm 0.02,84 \pm 0.04$, and $82 \pm$ $0.08 \%$ of baseline values.

Additional experiments $(n=4)$ confirmed that although the monolayers failed to respond to AVP, they were capable of having a marked increase in Isc in response to $8 \mathrm{Br}$ cAMP (Fig. 1). Similarly, monolayers $(n=7)$ increased their Isc to $172 \pm$ 
$7 \%$ of baseline values in response to IBMX $\left(10^{-3} \mathrm{M}\right)$, yet subsequent exposure to either 30 or $300 \mathrm{mU} / \mathrm{mL}$ AVP failed to further augment Isc.

The baseline bioelectric properties for monolayers $(n=8)$ in which we studied the effect of ANP were $\mathrm{PD}=3.5 \pm 0.4 \mathrm{mV}$, Isc $=6.5 \pm 0.5 \mu \mathrm{A} \cdot \mathrm{cm}^{-2}$, and $\mathrm{R}=553 \pm 53 \Omega \cdot \mathrm{cm}^{2}$. Sequential exposure of these monolayers to $10^{-11}, 10^{-10}, 10^{-9}$, and $10^{-8} \mathrm{M}$ ANP did not influence $P D, R$, or Isc. Isc after the respective log doses of ANP was $6.2 \pm 0.5,6.2 \pm 0.44,6.3 \pm 0.4$, and $5.9 \pm$ $0.5 \mu \mathrm{A} \cdot \mathrm{cm}^{-2}$. Two monolayers grown on collagen-coated nitrocellulose filters (Millipore HA; Millipore, Bedford, CT) (16) were similarly unaffected by $10^{-11}$ through $10^{-8} \mathrm{M}$ ANP. Similarly, cGMP did not affect the Isc of FLE (baseline $=4.6 \pm 0.71$ versus post cGMP of $4.4 \pm 0.67 \mu \mathrm{A} \cdot \mathrm{cm}^{-2}, n=3$ ).

A6 renal epithelium. In contrast to results for FLE, addition of AVP rapidly increased Isc of A6 cells (Table 3). Aldosterone pretreatment for $24 \mathrm{~h}$ affected the baseline bioelectric properties of A6 cells and their response to AVP (Tables 2 and 3).

cAMP levels. Baseline cAMP levels in IBMX-pretreated monolayers of A6 and FLE cells were different (respectively, $0.50 \pm$ 0.10 versus $10.6 \pm 0.58 \mathrm{pmol} \cdot \mathrm{mg}$ protein $\left.{ }^{-1}, p<0.05\right)$. As illustrated in Figure 2, 10-min exposure to the $\beta_{2}$-agonist terbutaline markedly increased cAMP levels in FLE but not A6 cells, whereas AVP markedly increased cAMP levels in A6 cells but not FLE cells. The most likely explanation of these results is that FLE possess $\beta_{2}$-receptors but lack $V_{2}$ receptors (or possibly the appropriate adjacent guanosine triphosphate binding protein).

\section{DISCUSSION}

The present experiments demonstrate that the bioelectric properties of primary monolayer cultures of FLE are unaffected by AVP despite having an intact CAMP second-messenger pathway. The data indicate that observations made in other tissues regarding the effect of AVP on sodium transport cannot necessarily be extrapolated to the mammalian lung.

FLE in primary culture are sodium-absorbing cells, as demonstrated by the ability of amiloride and benzamil to markedly reduce Isc and the inability of chloride transport blockers to affect ion transport by resting or $\beta_{2}$-agonist-stimulated monolayers (see Results and Ref. 16). Our laboratory has also recently demonstrated, using ion substitution experiments, that the entire Isc (amiloride sensitive and insensitive) is dependent upon the presence of sodium ions on the apical membrane of the cells (3).

Possible explanations for the inability of AVP to affect the

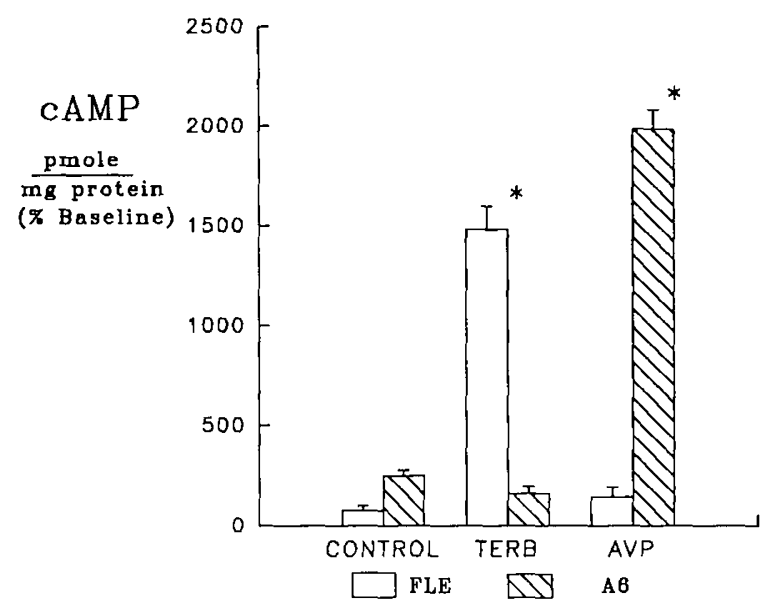

Fig. 2. A $10-\mathrm{min}$ exposure to terbutaline $\left(10^{-5} \mathrm{M}\right.$, terb $)$ increased endogenous CAMP levels above baseline levels in fetal lung epithelial cells (FLE, open bars) but not A6 cells (hatched bars). A similar length of exposure to AVP $(300 \mathrm{mU} / \mathrm{mL})$ increased cAMP levels in A6 but not FLE cells. cAMP levels are normalized to $\mathrm{mg}$ total protein of similarly prepared cell monolayers and expressed as a percentage of baseline $(\mathrm{t}=$ $0 \mathrm{~min}$ ) values. ${ }^{*}, p<0.05$ relative to respective cell type's baseline value. bioelectric properties of FLE include the absence of receptors or defective signal transduction pathways. The former explanation is most likely, inasmuch as our experiments have demonstrated that FLE do not increase cAMP levels when exposed to AVP (Fig. 2). This speculation is supported by studies of adult type II alveolar epithelium in which it was demonstrated that AVPstimulated surfactant secretion occurred via $V_{1}$ receptors and a $\mathrm{Ca}^{++}$and protein kinase C-dependent mechanism (15). Indeed, they (15) demonstrated that AVP did not stimulate adenylate cyclase activity in the adult type II alveolar epithelium, thus suggesting that these cells lack $V_{2}$ receptors (15). It is known that the natriuretic effect of AVP in other tissues occurs via elevation of cAMP levels (e.g. Ref. 8); however, present and previous results from our laboratory suggest that the cAMP pathway is intact in these alveolar epithelial cells. First, these cells increase sodium transport in response to the $\beta_{2}$-agonist terbutaline ( 3 , 16 ), a response that presumably occurs via guanosine-triphosphate binding proteins and the adenylate cyclase/cAMP signal transduction pathway. Second, our present results also demonstrate that these cells respond to membrane-permeant cAMP analogs or to elevation of endogenous cAMP levels by exposing the cells to the phosphodiesterase inhibitor IBMX. Even in the presence of IBMX, large concentrations of AVP did not affect Isc. Third, the $\beta_{2}$-agonist terbutaline increases endogenous cAMP levels (Fig. 2). Thus, it is likely that these fetal cells do not possess $\mathrm{V}_{2}$ receptors for AVP.

Our observations contrast with the conclusions made from previous in vivo studies, which showed that i.v. but not intraalveolar AVP causes a reduction in lung fluid secretion rate in the fetal goat (4) or lamb (5). There are several important points regarding these previous studies. First, these studies did not determine whether amiloride could block the AVP effect, so the mechanism of AVP's action is unknown. Second, i.v. AVP did not induce fluid absorption in the intact fetal lamb unless it was infused into fluid-overinflated fetal lungs (4) or during labor (5). Finally, the doses of AVP used in these studies $(4,5)$ were very high. Basal plasma AVP concentration is in the range of 0.0004 $\mathrm{mU} / \mathrm{mL}(24,25)$ in adult humans. Studies in newborn infants have shown that if umbilical and vein plasma AVP concentrations are averaged, the AVP concentration at birth transiently peaks at a mean value of approximately $0.3 \mathrm{mU} / \mathrm{mL}$ in vaginal deliveries and at $0.03 \mathrm{mU} / \mathrm{mL}$ in cesarean section (in labor) deliveries then rapidly returns toward basal values $(6,26)$. This contrasts with the continuous high-dose infusions used by previous investigators $(4,5)$, who obtained mean plasma levels of $0.23 \mathrm{mU} / \mathrm{mL}$.

There are several additional potential explanations for this apparent discrepancy between our data and those previous in vivo studies $(4,5)$. There may be species differences between the rat and ovine species, inasmuch as it has been shown that AVP can have different effects on the same tissue from different species, e.g. AVP increases sodium transport in the rat's (8) but not rabbit's (9) cortical collecting duct. A second possibility is that there may be regional differences within the lung. Our results, however, agree with Boucher and Gatzy (12), who showed that AVP does not affect sodium transport by the rabbit tracheal epithelium. A third possibility is that AVP's reduction of fluid secretion in the fetal goat and lamb is not a direct effect, but rather is a secondary phenomenon associated with the welldescribed AVP-induced changes in hemodynamics $(4,5)$. Finally, it is possible that our in vitro distal lung epithelia are not representative of their function in vivo. Which of these several possible explanations is correct is unknown.

The effect of AVP on Na transport by adult alveolar type II epithelial cells is controversial. AVP increases dome formation (13); however, our present results agree with those of Cott $e t$ al. (14), who showed that AVP had no effect on the bioelectric properties of adult type II alveolar epithelial cells. Measurement of Isc is a direct measurement of ion transport, whereas dome formation may be influenced by many factors other than sodium 
channel activity (e.g. tight junctions, substratum matrix composition, and transport of other ions).

The lack of effect of ANP in our fetal cells is consistent with observations that ANP did not affect lung water clearance in an animal model of pulmonary edema (27). Similar to the study by Cott et al. (14), who showed that the bioelectric properties of adult type II epithelium are unaffected by cGMP [the putative intracellular mediator of ANP's action in responsive epithelium (23)], in our study cGMP did not affect the bioelectric properties of our FLE. These data provide further evidence that the mammalian lung epithelium may not respond in the same manner as does renal and especially amphibian epithelium.

Aldosterone pretreatment of monolayers did not affect baseline bioelectric properties of FLE or its response to AVP. This is in agreement with a previous report demonstrating that aldosterone affects neither rabbit tracheal sodium transport (12) nor the nasal respiratory epithelial PD in normal subjects and patients with cystic fibrosis (28). These two reports and our data contrast with two other studies performed in the lung. Aldosterone had a small effect on canine tracheal epithelial sodium transport (29); however, this study used unusual conditions (chloride-free solutions) and a 2-d incubation in high-dose aldosterone $\left(10^{-6} \mathrm{M}\right)$. Fischer and Clauss (30) have reported that aldosterone regulates sodium channels in frog lung epithelium; however, their study again raises the possibility that much of our knowledge arising from the effect of AVP and aldosterone on sodium transport in amphibian tissues should not necessarily be extrapolated to the mammalian alveolus.

In conclusion, our study demonstrated that neither AVP nor ANP alter the bioelectric properties of FLE and raised the possibility that AVP may not directly promote sodium absorption at the time of birth.

\section{REFERENCES}

1. Olver RE, Ramsden CA, Strang LB, Walters DV 1986 The role of amilorideblockade sodium transport in adrenaline-induced lung liquid reabsorption in the fetal lamb. J Physiol 376:321-340

2. O'Brodovich H, Hannam V, Seear M, Mullen JBM 1990 Amiloride impairs lung water clearance in newborn guinea pigs. $J$ Appl Physiol 68:1758-1762

3. O'Brodovich H, Hannam V, Rafii B 1991 Sodium channel but neither $\mathrm{Na}^{+}$ $\mathrm{H}^{+}$nor Na-glucose symport inhibitors slow neonatal lung water clearance. Am J Respir Cell Mol Biol 5:377-384

4. Perks AM, Cassin S 1989 The effects of arginine vasopressin and epinephrine on lung liquid production in fetal goats. Can $\mathbf{J}$ Physiol Pharmacol 67:491498

5. Wallace J, Hooper S, Harding R 1990 Regulation of lung liquid secretion by arginine vasopressin in fetal sheep. Am J Physiol 258:R 104-R 111

6. Chard T, Hudson CN, Edwards CRW, Boyd NRH 1971 Release of oxytocin and vasopressin by the human fetus during labour. Nature 234:352-354

7. Handler J, Preston AS, Orloff J 1969 Effect of adrenal steroid hormones on the response of the toad's urinary bladder to vasopressin. J Clin Invest 48:823-833

8. Schafer JA, Troutman SL 1990 cAMP mediates the increase in apical membrane $\mathrm{Na}$ conductance produced in rat CCD by vasopressin. Am J Physio 259:F823-F831

9. Chen L, Williams SK, Schafer JA 1990 Differences in synergistic actions of vasopressin and deoxycorticosterone in rat and rabbit CCD. Am J Physiol 259:F147-F156

10. Marunaka X, Eaton DC 1991 Effects of vasopressin and CAMP on single amiloride-blockable Na channels. Am J Physiol Cell Physiol 260:C1071C1084

11. Zusman RM, Keiser HR, Handler J 1978 Effect of adrenal steroids on vasopressin-stimulated PGE synthesis and water flow. Am J Physiol 234:F532-F540

12. Boucher RC, Gatzy JT 1983 Characteristics of sodium transport by excised rabbit trachea. J Appl Physiol 55:1877-1883

13. Goodman BE, Brown SES, Crandall ED 1984 Regulation of transport across pulmonary alveolar epithelial monolayers. J Appl Physiol 57:703-710

14. Cott GR, Sugahara K, Mason RJ 1986 Stimulation of net active ion transport across alveolar type II cell monolayers. Am J Physiol 250:C222-C227

15. Brown LAS, Wood LH 1989 Stimulation of surfactant secretion by vasopressin in primary cultures of adult rat type II pneumocytes. Biochim Biophys Acta $1001: 76-81$

16. O'Brodovich H, Rafii B, Post M 1990 Bioelectric properties of fetal alveolar epithelial monolayers. Am J Physiol 258:L201-L206

17. Orser BA, Bertlik M, Fedorko L, O'Brodovich H 1991 Non-selective cation channel in fetal alveolar type II epithelium. Biochim Biophys Acta 1094:1926

18. Paccolat MP, Geering K, Gaeggeler HP, Rossier BC 1987 Aldosterone regulation of $\mathrm{Na}^{+}$transport and $\mathrm{Na}^{+}-\mathrm{K}^{+}$-ATPase in $\mathrm{A} 6$ cells: role of growth conditions. Am J Physiol 21:C468-C476

19. Wade JB, Stanton BA, Field MJ, Kashgarian M, Giebisch G 1990 Morphological and physiological responses to aldosterone: time course and sodium dependence. Am J Physiol 259:F88-F94

20. Battenburg JJ, Otto-Verberne CJM, Ten Haye-Opbrock AAW, Ktazinga W 1988 Isolation of alveolar type II cells from fetal rat lung by differential adherence in monolayer culture. Biochim Biophys Acta 960:441-453

21. Post M, Smith BT 1988 Histochemical and immunocytochemical identification of alveolar type II epithelial cells isolated from fetal rat lung. Am Rev Respir Dis 137:525-530

22. Garty H, Benos DJ 1988 Characteristics and regulatory mechanisms of the amiloride-blockable $\mathrm{Na}^{+}$channel. Physiol Rev 68:309-373

23. Brenner BM, Ballermann BJ, Gunning ME, Zeidel ML 1990 Diverse biologic actions of atrial natriuretic peptide. Physiol Rev 70:665-699

24. Andrew M, O'Brodovich H, Coates G, Robertson GL, Gray GW 1985 Hypoxia-induced vasopressin release and coagulopathy in a normal subject. Aviat Space Environ Med 56:1220-1223

25. Rittig S, Knudsen UB, Jonler M, Norgaard JP, Pedersen EB, Diurhuus JC 1989 Adult enuresis. The role of vasopressin and atrial natriuretic peptide. Scand J Urol Nephrol 125:79-86

26. Phojavuori M, Fyhrquist F 1980 Hemodynamic significance of vasopressin in the newborn infant. J Pediatr 97:462-465

27. Olivera W, Ridge K, Wood LDH, Sznajder JI 1991 Atrial natriuretic factor (ANF) reduces edema clearance in isolated rat lungs. FASEB J 5:A1730 (abstr)

28. Knowles MR, Gatzy JT, Boucher RC 1985 Aldosterone metabolism and transepithelial potential difference in normal and cystic fibrosis subjects. Pediatr Res 19:676-679

29. Cullen JJ, Weish MJ 1987 Regulation of sodium absorption by canine tracheal epithelium. J Clin Invest 79:73-79

30. Fischer $\mathrm{H}$, Clauss W 1990 Regulation of $\mathrm{Na}^{+}$channels in frog lung epithelium: a target tissue for aldosterone action. Pflugers Arch 416:62-67 